\title{
Cloning in Bacillus subtilis by Transfection with Bacteriophage Vector $\phi 105 J 27$ : Isolation and Preliminary Characterization of Transducing Phages for 23 Sporulation Loci
}

\author{
By J. ERRINGTON* AND D. JONES $\dagger$ \\ Microbiology Unit, Department of Biochemistry, University of Oxford, South Parks Road, \\ Oxford OXI $3 Q U, U K$
}

(Received 13 August 1986; revised 20 October 1986)

\begin{abstract}
Bacteriophage cloning vector $\phi 105 \mathrm{~J} 27$, the construction of which is described in an accompanying paper, has been used for shotgun cloning of sporulation genes in Bacillus subtilis. Various genomic libraries have been constructed and screened for the presence of recombinant phages capable of transducing strains containing sporulation $(s p o)$ mutations to $\mathrm{Spo}^{+}$. Of a total of 30 spo loci tested, transducing phages have been isolated for 23, more than half of the known spo loci. Included are nine loci (spo0D, spo0J, spoIIIA, spoIIIE, spoIIIF, spoIVF, spoVB, spoVH and spoVJ) that do not appear to have been cloned previously. Preliminary genetic characterization of some of the new clones by a rapid screening procedure has enabled the status of various sporulation loci to be clarified.
\end{abstract}

\section{INTRODUCTION}

Endospore formation in Bacillus subtilis represents a simple model system for cellular development and differentiation. Since genetic methods for use in this organism are now quite sophisticated, this developmental system is amenable to study at the molecular level. The isolation of mutations that interfere with development (spo) has enabled many of the genes controlling the process to be identified. About 50 genetic loci have been identified (Piggot \& Coote, 1976; Piggot \& Hoch, 1985b). These 'loci' were defined mainly on the basis of genetic mapping of spo mutations by transduction or transformation, and by the phenotypic consequences of mutation. Gene cloning and sequencing have shown that some spo loci are polycistronic, while others are monocistronic (see for example: Lopez-Diaz et al., 1986; Fort \& Errington, 1985). However, the absence of a reliable and efficient means of cloning genes in Bacillus has, until recently, made similar analyses of the majority of spo loci difficult.

The accompanying paper (Jones \& Errington, 1987) describes the construction of a new serries of cloning vectors that improve the efficiency of a $B$. subtilis cloning system based on direct transfection of protoplasts with DNA from bacteriophage $\phi 105$ (Errington, 1984). The getieral advantages of this cloning system have been fully discussed previously (Errington, 1984). This paper describes the use of one of the new vectors, $\phi 105 \mathrm{~J} 27$, to construct $B$. subtilis genomic libraries, and the isolation and preliminary characterization of 31 new recombinant phages, capable of transducing to $\mathrm{Spo}^{+}$strains harbouring mutations in a total of 23 spo loci.

\section{METHODS}

Bacterial strains. B. subtilis $168 \operatorname{trpC2}$ is a sporogenic laboratory wild-type strain. The various spo mutants that were employed are listed in Table 1.

Preparation of phage. The methods of Jenkinson \& Mandelstam (1983) were used, as modified by Jones \& Errington (1987).

$†$ Permanent address: Department of Microbiology, University of Cape Town, Rondebosch 7700, South Africa. 
Table 1. Bacillus subtilis strains

\begin{tabular}{|c|c|c|c|}
\hline Strain & Genotype* $^{*}$ & Origin $†$ & \\
\hline 2.3 & lys-1 spoIIIB 2 & Piggot (1973) & (A3) \\
\hline 8 & $\operatorname{trpC2}$ spoIVC8 & Piggot (1973) & (E13) \\
\hline 17.2 & metC3 tal-1 spoOH17 & Waites et al. (1970) & (E22) \\
\hline 20 & $\operatorname{trpC2}$ spoIIE20 & Waites et al. (1970) & (N25) \\
\hline 21 & $\operatorname{trpC} 2$ spoIIE2I & Piggot (1973) & (U27) \\
\hline 23.1 & trpC2 spoIVC23 & Waites et al. (1970) & (E31) \\
\hline 26.2 & leuA8 tal-1 spoIIIA26 & Piggot (1973) & (E34) \\
\hline 35 & $\operatorname{trpC2}$ spoIIIA 35 & Waites et al. (1970) & (NG13) \\
\hline 36 & trpC2 spoIIIE36 & Piggot (1973) & (NG1.67) \\
\hline 41.1 & leuA8 tal-1 spoIIG4l & Piggot (1973) & (NG4.14) \\
\hline 43.6 & $\operatorname{trpC2} \operatorname{spo0A43}$ & Piggot (1973) & (NG6.21) \\
\hline 44.1 & metC3 tal-1 spoIIIA44 & Piggot (1973) & (NG7.2) \\
\hline 46 & $\operatorname{trpC2}$ spoOH46 & Piggot (1973) & (NG7.17) \\
\hline 48.7 & trpC2 spoIIE48 & Piggot (1973) & (NG9.3) \\
\hline 49.2 & metC3 tal-1 spoIIG49 & Piggot (1973) & (NG10.2) \\
\hline 53.1 & $\operatorname{trpC2}$ гров2 spollla53 & Piggot (1973) & (NG12.5) \\
\hline 55.2 & trpC2 rрo 22 spoIIG 55 & Piggot (1973) & (NG12.12) \\
\hline 59.2 & metC3 spoIIIA 59 & Piggot (1973) & (NG14.7) \\
\hline 60.1 & leuA8 rpoB2 spoIIE60 & Piggot (1973) & (NG14.22) \\
\hline 61.1 & leu $A 8$ rpoB2 spoIIE6I & Piggot (1973) & (NG15.4) \\
\hline 64.1 & leuA8 rpoB2 spoIIE64 & Piggot (1973) & (NG17.15) \\
\hline 65 & $\operatorname{trpC2}$ spoIIIA65 & Piggot (1973) & (NG17.17) \\
\hline 67 & $\operatorname{trpC2}$ spoIVA67 & Piggot (1973) & (NG17.23) \\
\hline 69.15 & $\operatorname{trp} C 2$ spoIIAA69 & Piggot (1973) & (NG18.6) \\
\hline 71.2 & $\operatorname{trpC} 2$ spoIIE7I & Piggot (1973) & (NG20.12) \\
\hline 79.2 & lys-1 spoIIIA79 & Hranueli et al. (1974) & \\
\hline 81.1 & leu $A 8$ rров2 spoOH81 & Hranueli et al. (1974) & \\
\hline 83 & metC3 leuA8 tal-I spoOH83 & Hranueli et al. (1974) & \\
\hline 85 & trpC2 spoVE85 & Hranueli et al. (1974) & \\
\hline 86.2 & metC3 tal-1 spollIA 86 & Hranueli et al. (1974) & \\
\hline 87.2 & leuA8 tal-1 spo0J87 & Hranueli et al. (1974) & \\
\hline 88.7 & $\operatorname{trpC2}$ spoIVF88 & Hranueli et al. (1974) & \\
\hline 90.2 & metC3 tal-1 spollIA90 & Hranueli et al. (1974) & \\
\hline 91 & $\operatorname{trpC} 2$ spoVB91 & Hranueli et al. (1974) & \\
\hline 92 & trpC2 metC3 rpoB2 spoIVD92 & Hranueli et al. (1974) & \\
\hline 93.2 & $\operatorname{trpC2}$ spo0J93 & Hranueli et al. (1974) & \\
\hline 133.1 & $\operatorname{trpC2}$ spoIVC133 & Coote $(1972 b)$ & $(\mathrm{Z7})$ \\
\hline 141 & $\operatorname{trpC} 2$ spooK 141 & Coote $(1972 a)$ & (Z31) \\
\hline 145 & $\operatorname{trpC2}$ spoIIIA 145 & Coote $(1972 a)$ & (Y9) \\
\hline 149.1 & pheA12 spoIVCI49 & Coote $(1972 b)$ & $(\mathrm{X} 2)$ \\
\hline 150.1 & pheA12 spoIIlA 150 & Coote $(1972 a)$ & (X3) \\
\hline 153.2 & pheA12 spoVE 153 & Coote $(1972 a)$ & (W5) \\
\hline 156 & $\operatorname{trp} C 2$ spoVD156 & Coote $(1972 a)$ & (W10) \\
\hline 158 & $\operatorname{trpC} 2$ spoIIIA 158 & Coote $(1972 a)$ & (W12) \\
\hline 163 & $\operatorname{trpC2}$ spoIIIA 163 & Coote $(1972 a)$ & (P4) \\
\hline 207.2 & pheA12 spoIVF 207 & Lamont (1983) & \\
\hline 221.1 & $\operatorname{trpC2}$ spoOF221 & Hoch \& Mathews (1973) & $($ spoF 221) \\
\hline 298.2 & pheA12 spoIID298 & Coote $(1972 a)$ & (P9) \\
\hline 484.2 & $\operatorname{trpC2}$ spoOE11 & Hoch \& Mathews (1973) & (spoEll) \\
\hline 485.1 & $\operatorname{trpC2}$ spo0G 14 & Ionesco et al. (1970) & (14UL) \\
\hline 486 & $\operatorname{trpC} 2$ spoOD8 & Ionesco et al. (1970) & $(8 \mathrm{H})$ \\
\hline 488.1 & $l y s-1$ spo0B 136 & Hoch \& Mathews (1973) & $($ spoB 136) \\
\hline 496 & trpC2 spoIIIC94 & Ionesco et al. (1970) & $(94 \mathrm{U})$ \\
\hline 497.1 & trpC2 spoIIID 83 & Ionesco et al. (1970) & $(83 \mathrm{U})$ \\
\hline 498 & trpC2 spoIVEII & Ionesco et al. (1970) & $(11 \mathrm{~T})$ \\
\hline 516 & trpC2 spoVH516 & Hill (1983) & \\
\hline 517 & $\operatorname{trpC2}$ spoVJ517 & Hill (1983) & \\
\hline 518 & $\operatorname{trpC2}$ spoVH5I8 & Hill (1983) & \\
\hline 522.2 & $\operatorname{trpC} 2 \operatorname{ger} E 36$ & Moir (1981) & \\
\hline 574.1 & lys-1 tal-1 spoVAA574 & Errington \& Mandelstam (1984) & \\
\hline 585 & lys-1 spoIVF585 & Lamont (1983) & \\
\hline 586 & lys-1 spoIVF586 & Lamont (1983) & \\
\hline 590.4 & trpC2 spoIIIF 590 & Lamont \& Mandelstam (1984) & \\
\hline IS233 & trpC2 pheAI spoOHAHind & Weir et al. (1984) & \\
\hline
\end{tabular}

* tal- 1 , resistance to $\beta$-thienylalanine.

$\dagger$ Strain isolation numbers or previous designations of mutant alleles are given in parentheses. 
Preparation of DNA. Chromosomal DNA from strain 168, and phage DNA, were prepared as described previously (Errington, 1984).

Ligations. Chromosomal DNA (about $500 \mathrm{ng}$ ) and $\phi 105 \mathrm{~J} 27$ DNA (BamHI digested, about $200 \mathrm{ng}$ ) were ligated in $50 \mu \mathrm{l}$ reaction volumes for $16 \mathrm{~h}$ at $4{ }^{\circ} \mathrm{C}$ as described previously (Errington, 1984). The chromosomal DNA was prepared in three ways: partial digestion with $B c l$, complete digestion with $B g l \mathrm{II}$ or partial digestion with $\mathrm{MboI}$ followed by size fractionation on BRL low-melting-point agarose $(0.6 \%, \mathrm{v} / \mathrm{v})$ to the range 3 to $4 \mathrm{kbp}$. This DNA was recovered using the method recommended by the suppliers.

Protoplast transfection. Protoplasts of strain CU267 were prepared using the method of Chang \& Cohen (1979) as modified by Levi-Meyrueis et al. (1980). Methods for transfection with ligated DNA samples in the presence of polyethylene glycol, growth and recovery of recombinant phage pools were as described previously (Errington, 1984) except that the growth temperature was $30^{\circ} \mathrm{C}$.

Isolation of recombinant phages. Samples $(50 \mu \mathrm{l})$ of recombinant phage pools were mixed with phage-sensitive recipient cells $\left(400 \mu \mathrm{l}\right.$ of mid-exponential phase culture grown in Difco Penassay broth at $\left.37^{\circ} \mathrm{C}\right)$ and plated on Schaeffer's agar (Schaeffer et al., 1965). After incubation for $40 \mathrm{~h}$ at $30^{\circ} \mathrm{C}, \mathrm{Spo}^{+}$transductants were selected by treatment with $\mathrm{CHCl}_{3}$ vapour (Hoch, 1971) for $4 \mathrm{~h}$ at $22^{\circ} \mathrm{C}$. Spo ${ }^{+}$transductants, which appeared after 2 to $3 \mathrm{~d}$ reincubation at $30^{\circ} \mathrm{C}$, were pooled, and small-scale $(5 \mathrm{ml})$ phage lysates were prepared by temperature induction (Jones \& Errington, 1987). For highly oligosporogenous test strains containing mutations spo0E11, spo0J87, spo0J93, spo0K141, spoIIIA26, spoIVF88, spoVH516 and spoVJ517, it was not possible to identify Spo ${ }^{+}$ transductants among the large numbers of survivors. Instead, after several days of regrowth, the plates were replica plated to Oxoid nutrient agar and incubated for approximately $12 \mathrm{~h}$ at $30^{\circ} \mathrm{C}$ to allow vegetative growth to be resumed. A lysate was then prepared from all of the pooled survivors. Lysates were tested for further transduction to $\mathrm{Spo}^{+}$by one of two methods. Portions $(20 \mu \mathrm{l})$ of serial 100 -fold dilutions were spotted on to lawns of mid-exponential phase cells (grown as already described) on Schaeffer's agar. After a further period of growth, selection for $\mathrm{Spo}^{+}$cells was carried out (see above). Alternatively, and mainly for lysates made from purified strains, a $100 \mu \mathrm{l}$ sample of undiluted lysate (about $10^{9}$ p.f.u.) was spread over half of the surface of a Schaeffer's agar plate and allowed to dry. Strains to be tested for complementation (up to 12 per $9 \mathrm{~cm}$ plate) were then streaked across the plate from the unseeded area into the seeded area using a sterile toothpick. Growth and $\mathrm{Spo}^{+}$selection were as above. (After incubation for only $12 \mathrm{~h}$ it was possible to check that the recipient strain was phage sensitive by the break in cell density apparent at the boundary between seeded and unseeded areas. This break did not occur in phage-resistant or immune strains and is a useful rapid test for phage immunity.) Complementation of the spo mutation was evident several days after treatment with $\mathrm{CHCl}_{3}$ by confluent regrowth on only the phage-infected side of the plate. Where complementation did not occur, regrowth was either absent (for $\mathrm{Spo}^{-}$strains), or partial and more or less uniform along the complete streak (for oligosporogenous strains). Moreover, when complementation occurred, the surviving lysogens were phenotypically $\mathrm{Spo}^{+}$in terms of both pigmentation and the presence of phase-bright spores. Phages that did not complement but were able to transduce a Spo ${ }^{-}$mutant to $\mathrm{Spo}^{+}$by marker rescue recombination (see Results and Discussion and Fig. 1) gave rise to a stippled appearance following regrowth, as most of the infected cells remained $\mathrm{Spo}^{-}$. Again, the survivors were phenotypically $\mathrm{Spo}^{+}$ rather than mutant.

Induction of sporulation. Cells were grown in hydrolysed casein medium then induced to sporulate by resuspension in sporulation medium as described by Sterlini \& Mandelstam (1969). Times (h) after resuspension are denoted $t_{1}, t_{2}, t_{3}$, etc. Growth and sporulation at $37^{\circ} \mathrm{C}$ did not seem to cause significant loss of cells by phage induction.

Assay of heat resistant spores. A sample $(1 \mathrm{ml})$ of sporulating culture at $t_{9}$ was heated at $85^{\circ} \mathrm{C}$ for $15 \mathrm{~min}$. Suitable dilutions were plated on Oxoid nutrient agar and incubated at $30^{\circ} \mathrm{C}$. Colonies were counted after $2 \mathrm{~d}$ at $30^{\circ} \mathrm{C}$.

\section{RESULTS AND DISCUSSION}

\section{Construction and screening of $B$. subtilis genomic libraries}

Chromosomal DNA from $B$. subtilis strain 168 was partially digested with $M b o$ I and the fragments were size fractionated to the range of 3 to $4 \mathrm{kbp}$. About $200 \mathrm{ng}$ of this DNA was ligated to about $500 \mathrm{ng}$ of the vector, $\phi 105 \mathrm{~J} 27$, that had been cleaved at its unique BamHI site. After transfection of strain CU267 protoplasts, about $10^{5}$ p.f.u. were obtained and the progeny phage were recovered as four independent pools of roughly equal size. A series of sporulation mutants were screened for transduction by the library of recombinant phages as described in Methods. $\mathrm{Spo}^{+}$survivors were pooled, temperature induced and the sterilized lysates were tested for a second round of $\mathrm{Spo}^{+}$transduction. Successful cloning was indicated by high frequency transduction of the Spo ${ }^{+}$phenotype. Most strains were tested for transduction by a mixture of phage particles from all four pools. Several strains were tested against each individual pool and 
Table 2. Screening B. subtilis genomic libraries constructed with phage $\phi 105 J 27$ for the presence of sporulation loci

Chromosomal DNA from B. subtilis strain 168 was prepared in various ways (see Methods) for cloning in $\phi 105 \mathrm{~J} 27$. After transfection of recipient strain CU267, the resultant pools of progeny phage were screened for the ability to transduce each of a series of strains containing spo mutations to $\mathrm{Spo}^{+}$by selection for resistance to $\mathrm{CHCl}_{3}$ vapour. A space indicates that screening was not carried out. A dash indicates that screening was performed but that no transduction was detected. Where selection was successful, the designation of the recombinant phage isolated is given.

\begin{tabular}{|c|c|c|c|c|}
\hline \multirow{2}{*}{$\begin{array}{l}\text { spo mutation } \\
\text { tested }\end{array}$} & \multicolumn{4}{|c|}{ Genomic library screened: } \\
\hline & MboI-A & $M b o \mathrm{I}-\mathrm{B}$ & $B c l \mathrm{I}$ & $B g l \mathrm{II}$ \\
\hline spo0A43 & - & & & \\
\hline spo0B 136 & $\phi 105 \mathrm{~J} 39$ & & & \\
\hline spo0D8 & & $\phi 105 \mathrm{~J} 96$ & - & - \\
\hline spo0E11 & - & - & - & - \\
\hline spoOF 221 & $\phi 105 \mathrm{~J} 40$ & & & \\
\hline spo0G 14 & - & - & $\phi 105 \mathrm{~J} 94$ & - \\
\hline spo0H46 & & $\phi 105 \mathrm{~J} 80$ & - & - \\
\hline spo0J87* & - & $\phi 105 \mathrm{~J} 92$ & $\phi 105 \mathrm{~J} 93$ & - \\
\hline spoOKI4I & - & - & - & - \\
\hline spoIIAA69 & $\phi 105 \mathrm{~J} 32$ & & & $\phi 105 \mathrm{~J} 84$ \\
\hline spoIID298 & $\phi 105 \mathrm{~J} 33, \phi 105 \mathrm{~J} 34$ & & $\phi 105 \mathrm{~J} 85$ & \\
\hline spoIIE61. & - & - & - & $\phi 105 \mathrm{~J} 97$ \\
\hline spollG55 & - & $\phi 105 \mathrm{~J} 95$ & - & - \\
\hline spoIIIA26* & - & - & $\phi 105 \mathrm{~J} 83$ & - \\
\hline spoIIIB 2 & $\phi 105 \mathrm{~J} 35$ & & & \\
\hline spoIIIC94 & - & & & \\
\hline spoIIID83 & - & - & - & - \\
\hline spoIIIE36 & $\phi 105 \mathrm{~J} 30, \phi 105 \mathrm{~J} 31$ & & & \\
\hline spoIIIF590 & - & & & \\
\hline spoIVA67 & - & - & - & - \\
\hline spoIVC23 & - & $\phi 105 \mathrm{~J} 79, \phi 105 \mathrm{~J} 91$ & $\phi 105 \mathrm{~J} 78$ & - \\
\hline spoIVEII & - & - & - & - \\
\hline spoIVF88 & $\phi 105 \mathrm{~J} 36$ & & & \\
\hline spoVAA574 & $\phi 105 \mathrm{~J} 41$ & & & \\
\hline spoVB91 & - & - & - & $\phi 105 \mathrm{~J} 86$ \\
\hline spoVD156 & - & & & \\
\hline spoVE85 & $\phi 105 \mathrm{~J} 37$ & & & \\
\hline spoVH516 & & $\phi 105 \mathrm{~J} 87 \dagger$ & $\phi 105 \mathrm{~J} 88 \dagger$ & $\phi 105 \mathrm{~J} 98$ \\
\hline spoVJ517 & & $\phi 105 \mathrm{~J} 81$ & $\phi 105 \mathrm{~J} 82$ & - \\
\hline gerE36 & $\phi 105 \mathrm{~J} 44 \dagger$ & & & \\
\hline
\end{tabular}

* MboI-A library was screened against mutations spo0J93 and spollIA59 rather than the mutations shown. † These phages were isolated by $\mathbf{S}$. M. Cutting.

in such cases more than one independent transducing phage was sometimes isolated. The results of the screening process, and the designations of the new recombinant phages, are shown in Table 2. In this original experiment (' $M b o \mathrm{I}-\mathrm{A}$ ' library), ten transducing phages were obtained from the 26 loci tested, a success rate of about $40 \%$.

All but two of the loci cloned (spoIIIE and spoIVF) have been cloned previously, whereas only 3 of the 16 loci not cloned (spoOA, spoIIG and spoIVC) have been cloned in $\phi 105$ in experiments reported elsewhere (although several have been cloned by other means; see below).

To determine whether other sporulation genes can be cloned in $\phi 105$ by transfection, three new genomic libraries were constructed and screened, using target DNA prepared in various ways. One ('MboI-B') was constructed by the same procedure except that the concentration of target DNA was increased by about twofold. The other libraries contained chromosomal DNA digested with $B c l I$ (partial digestion) or BglII (complete digestion). Table 2 also shows the results of the subsequent screening experiments, which were mainly concerned with spo loci that had not already been cloned. Seven of the loci not cloned in the first experiment, spo0G, spo0J, 
spoIIG, spoIIE, spoIIIA, spoIVC and spoVB, were isolated from these new libraries. In addition, phages containing four loci that had not been screened for transduction in the first library, spoOD, spoOH, spoVH and spoVJ, were isolated. Mutations in two additional loci, spoOA and spoIIIF, were found to be complemented by phages transducing mutations in loci known to be closely linked (spoOG and spoVB respectively; see below). In summary, out of 30 loci tested in all, transducing phages were isolated for 23 , a success rate of about $77 \%$.

It appears, therefore, that transfection with $\phi 105 \mathrm{~J} 27$ is an effective means of cloning sporulation genes and, presumably, B. subtilis genes generally. Although each individual library gave a relatively poor success rate (between 23 and $47 \%$ ), the overall rate was good. This suggests that cloning in this system is mainly dependent upon the distribution of restriction sites around each target gene. If more than one method for preparation of chromosomal DNA is used, the chances of success for any given gene appear to be enhanced. This may be a result of the relatively small size (about $4 \mathrm{kbp}$ ) of inserts that can be accommodated in the current $\phi 105$ vectors. It seems likely that further application of the methods described here and previously (Errington, 1984) (perhaps using other restriction enzymes to prepare the target DNA, and synthetic adaptor molecules), should enable us to clone most, if not all, of the remaining spo loci.

\section{Further characterization of the transducing phages}

An important advantage of the use of the $\phi 105$ transfection system for cloning $B$. subtilis genes is that non-defective phage vectors provide a rapid means of complementation analysis (Fort \& Errington, 1985), and of mutant strain verification. The latter facility has become increasingly important in recent experiments in which the whole spectrum of spo mutations is being used to define the pathways of genetic regulation during sporulation (Errington \& Mandelstam, $1986 a$, $b$; Clarke et al., 1986; Turner et al., 1986). The simple cross-streaking procedure described in Methods was used to determine the abilities of various phages to transduce other mutations thought to lie in or near the newly-cloned spo loci. An example of the results obtained with this test is shown in Fig. 1. The following loci were not considered further because they have already been characterized in some detail: spoOB (Ferrari et al., 1985a); spoOF (Trach et al., 1985); spoIIA (Fort \& Piggot, 1984); spoIID (Lopez-Diaz et al., 1986); spoVA (Fort \& Errington, 1985); spoVE (Piggot et al., 1986); gerE (Cutting \& Mandelstam, 1986). The results of studies with the remaining clones are summarized below.

spo0D. Phage $\phi 105 \mathrm{~J} 96$ complemented the single known spo0D mutation, spo0D8 (mutant $8 \mathrm{H}$ of Ionesco et al., 1970). It did not complement mutations in spoIIIC, spoIIID, spoIVC, spoIVD or spoIVE; loci which are thought to lie nearby (Piggot \& Coote, 1976). However, it did complement the spo0B136 mutation, supporting the suggestion (J. A. Hoch, personal communication) that $s p o 0 D 8$ is actually an allele of $s p o 0 B$.

spo0G. The spo0G locus was defined (Piggot \& Coote, 1976) by a single mutation, spo-14 (mutant 14UL of Ionesco et al., 1970), that appeared, on the basis of co-transduction frequencies, to be distinct from the spoOA locus. Indeed the latest $B$. subtilis genetic map (Piggot \& Hoch, $1985 a$ ) shows spo0A and spo0G separated by seven other markers, including the spoIIIA and spoIIIB loci. However, it has been suggested (J. A. Hoch, personal communication) that mutation spo0G14, like spoOD8 above, has been incorrectly mapped, and actually lies in the spoOA locus. Phage $\phi 105 \mathrm{~J} 94$ was therefore tested for complementation of mutation $s p o 0 A 43$ and a positive result was obtained. Although it is possible that this phage contains non-contiguous fragments of chromosomal DNA it seems most likely that mutation spo-14 lies within the spo0 A locus, which consists of a single gene (Ferrari et al., 1985b). Whether or not this is true, it appears that the $\operatorname{spoOA}$ locus has also been cloned in $\phi 105 \mathrm{~J} 27$.

spo0H. The homologous gene from Bacillus licheniformis has been cloned and sequenced (Ramakrishna et al., 1984) but there remains some doubt about the integrity of the $B$. subtilis clone described by Weir et al. (1984). The plasmid isolated by these authors contained several non-contiguous fragments of $B$. subtilis chromosome and it did not appear to include the natural 


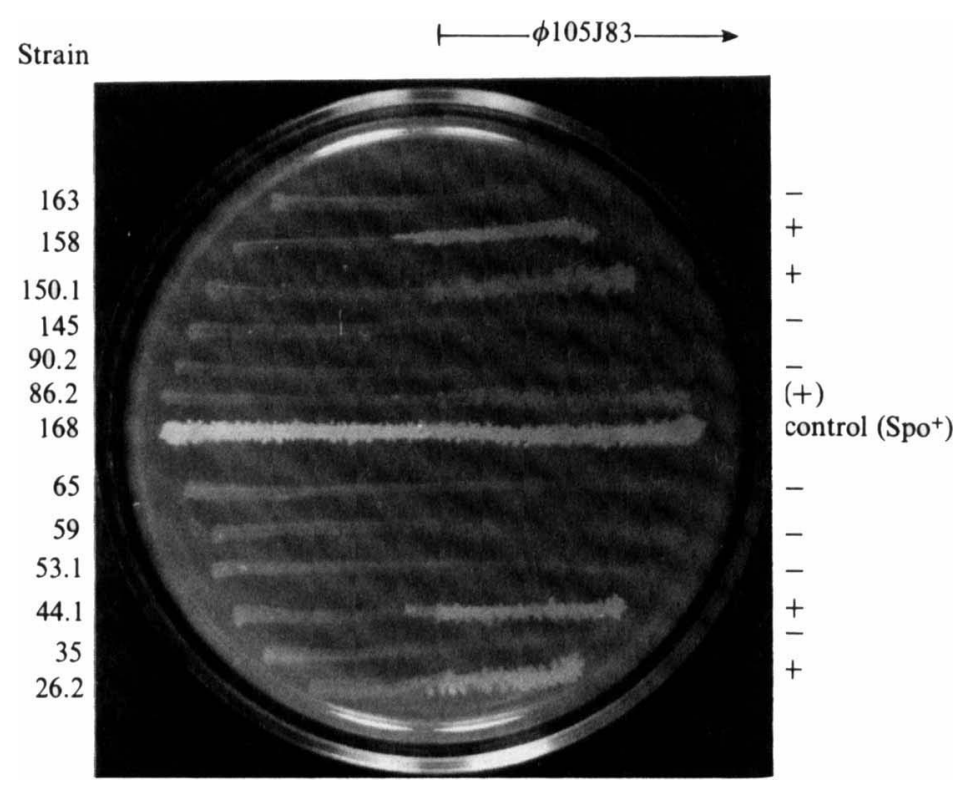

Fig. 1. Example of the rapid plate test for complementation and marker rescue of spo mutations by phage $\phi 105$ derivatives. The right-hand side of the plate (a $9 \mathrm{~cm}$ glass dish containing Schaeffer's agar) was seeded with recombinant phage, $\phi 105 \mathrm{~J} 83$, which contains a part of the spoIIIA locus. A series of strains containing spoIIIA mutations, and a control $\mathrm{Spo}^{+}$strain, 168, were streaked across the plate from left to right. After incubation at $30^{\circ} \mathrm{C}$ for $36 \mathrm{~h}$ the plate was exposed to $\mathrm{CHCl}_{3}$ vapour to kill vegetative cells and defective spores. The plate was then reincubated at $30^{\circ} \mathrm{C}$ for $3 \mathrm{~d}$ to allow regrowth of the survivors. Strains (numbered on the left) showing extensive regrowth in the phage-seeded area of the plate, + , have a spo mutation that is complemented by the phage. The remaining strains are not complemented, - , but strain 86.2 shows relatively low-frequency survival in the phage seeded area $(+)$, indicating that its spo mutation is not complemented but can be rescued by recombination with the DNA carried by the phage.

spoOH promoter. Phage $\phi 105 \mathrm{~J} 80$ complemented all of the spoOH mutations tested, including one, spoOH $\Delta H$ ind, derived by in vitro mutagenesis of the $s p o 0 H$ region (Weir et al., 1984).

spo0J. Two mutations, spo0J87 and spo0J93, define this locus but they are apparently quite widely separated in terms of transformation linkage (recombination index, RI, 0.39; Hranueli et al., 1974). Phages $\phi 105 \mathrm{~J} 92$ and $\phi 105 \mathrm{~J} 93$ both gave clear positive results in complementation tests with strain 87.2 but results with the highly oligosporogenous strain 93.2 were less clear cut. Derivatives of this latter strain, lysogenic for each of the phages, were therefore induced to sporulate by the resuspension method and at $t_{9}$ the cultures were assayed for heat-resistant spores. Cultures of strain 93.2 lysogenic for $\phi 105 \mathrm{~J} 92$ or $\phi 105 \mathrm{~J} 93$ showed no more heat-resistant spores than did the non-lysogenic control strain (about $5 \times 10^{3}$ c.f.u. $\mathrm{ml}^{-1}$ ). It also appeared that these phages did not rescue the spo0J93 mutation. These results, together with the relatively large RI observed for these mutations, suggest that they probably lie in two separate loci.

spoIIE. Phage $\phi 105 \mathrm{~J} 97$ was isolated from a $\mathrm{Spo}^{+}$transductant of strain 61.1 (spoIIE6I). However, lysates made from this strain and from subsequent $\mathrm{Spo}^{+}$transductants of the same strain gave only a relatively low frequency of transduction to $\mathrm{Spo}^{+}$. Most of the survivors of infection remained $\mathrm{Spo}^{-}$. We concluded that phage $\phi 105 \mathrm{~J} 97$ contains only a part of the spoIIE locus and does not complement in trans but can rescue the spoIIE61 mutation at low frequency by homologous recombination. Similar results were reported previously for a phage, $\phi 105 \mathrm{~J} 15$, which can complement mutations in the first three genes of the spoVA locus but gives only lowfrequency transduction, presumably by marker rescue recombination, of mutations in the fourth gene (Fort \& Errington, 1985). Phage $\phi 105$ J97 rescued four other spoIIE mutations, spo-20, 
spo-60, spo-64, and spo-71 but did not complement or rescue mutations spo-21, spo-39 or spo-48. The spoIIE locus is thought to be large and possibly polycistronic (M. Young, personal communication) so it is not surprising that only part of the operon appears to have been cloned in this instance.

spoIIG. At least part of the spoIIG locus has been cloned and sequenced (Stragier et al., 1984; Kobayashi \& Anaguchi, 1985) but it has been suggested that the locus is complex and may contain other genes (Kobayashi \& Anaguchi, 1985). Phage $\phi 105$ J95 complemented mutations spo-4I and spo-55, those used to define the gene sequenced by the above authors, but a third mutation, spo-49, appeared only to be rescued by recombination (see above). This mutation must therefore define a second gene in the spoIIG locus. Mutations spo-85 and spo-153, which lie in the nearby spoVE locus (Young, 1975), were not transduced by phage $\phi 105 \mathrm{~J} 95$.

spoIIIA. A large number of spoIIIA mutations have been classified (Piggot \& Coote, 1976). In view of the range of sporulation phenotypes associated with these mutations it was suggested that they might lie in several genes. Of 12 putative spoIIIA mutations tested, four, spo-26, spo-44, $s p o-150$ and $s p o-158$, were complemented by phage $\phi 105 \mathrm{~J} 83$. Mutation $s p o-86$ was rescued by recombination at low frequency, the remainder were not transduced at a detectable frequency (Fig. 1). There would appear, therefore, to be at least two genes in the spoIIIA locus, and the failure to rescue the majority of mutations suggests that a substantial part of the locus has not been cloned. Mutation spo-2 in the nearby spoIIIB locus (Piggot \& Coote, 1976) was not transduced by phage $\phi 105 \mathrm{~J} 83$.

spoIIIB. This locus has been cloned previously in a defective derivative of phage $\phi 105$ (Jenkinson \& Mandelstam, 1983). Nucleotide sequence analysis and complementation analysis suggest that the locus contains a large gene and that the locus could be polycistronic (M. Deadman \& J. Mandelstam, personal communication). Five newly-isolated spoIIIB mutations were all complemented by phage $\phi 105 \mathrm{~J} 35$.

spoIIIE. phages $\phi 105 \mathrm{~J} 30$ and $\phi 105 \mathrm{~J} 31$ both complement all three known spoIIIE mutations, spo-36, spo-47 and spo-82, and have been shown to contain a single complete transcription unit (P. Butler \& J. Mandelstam, personal communication).

spoIVC. Dancer \& Mandelstam (1981) showed that the spoIVC locus contains at least two different genes, separate complementation groups being defined by mutations spo- 23 and spo133. This analysis has been extended to include 14 further spoIVC mutations, all of which fall into one or other of these cistrons (M. D. Yudkin, personal communication). A $\phi 105$ derivative with spoIVC+ transducing activity has been reported prevously but it was tested only for complementation of mutation spoIVC133 (Fujita \& Kobayashi, 1985). All three of the new spoIVC ${ }^{+}$transducing phages, $\phi 105 \mathrm{~J} 78, \phi 105 \mathrm{~J} 79$ and $\phi 105 \mathrm{~J} 91$, complemented all of the spoIVC mutations tested, which included representatives of both cistrons. None of the phages complemented mutations in the following loci, which it had been suggested were either in or closely linked to spoIVC (Piggot \& Coote, 1976): spoIIIC, spoIIID, spoIVD and spoIVE.

It was noted that strain 23.1 lysogenic for any of the spoIVC $C^{+}$recombinant phages had a rather translucent appearance on nutrient agar plates, unlike the normal appearance of $\mathrm{Spo}^{+}$strains, including other spoIVC mutants transduced with these phages. Nevertheless, phase-bright spores were always abundant when the 23.1 derivatives were examined by phase-contrast microscopy. A similar phenomenon was observed in complementation of spoVH mutants (see below).

spoIVF. In addition to spoIVF88, strains containing 11 other spoIVF mutations have been isolated, all of which give an oligosporogenous phenotype (Lamont, 1983). These mutations are thought to lie in at least two distinct genes. Strains containing mutations spo-88, spo-207, spo-585 and spo-586 were tested, representative of both genes, and all of them appeared to be complemented by $\phi 105 \mathrm{~J} 36$.

spoVB. A single mutation, spo-91, defines the spoVB locus (Piggot \& Coote, 1976) but Lamont 
\& Mandelstam (1984) described a very closely linked (RI 0.05) mutation, spo-590, in a new locus designated spoIIIF. Phage $\phi 105 \mathrm{~J} 86$ transduced both of these mutations, thus confirming their proximity and supporting the suggestion of Lamont \& Mandelstam (1984) that the mutations might lie in the same operon. Whatever the status of $S p o I I F$ is, it has also now been cloned in $\phi 105 \mathrm{~J} 27$.

spoVH. This and the following locus, spoVJ, were defined by mutations with unusual spore resistance properties (Hill, 1983). Although the three mutations in these loci had rather similar properties and had a similar chromosomal location, two loci could be distinguished by measuring cotransformation frequencies. Mutations spoVH516 and spoVH518 were both complemented by phages $\phi 105 \mathrm{~J} 87, \phi 105 \mathrm{~J} 88$ and $\phi 105 \mathrm{~J} 98$. Like the complementation of spoIVC23 described above, the complemented strains did not appear fully $\mathrm{Spo}^{+}$when lysogenic for any of the three phages, although numerous spores were always evident when cultures of such lysogens were examined by phase-contrast microscopy. It seems unlikely that in all of the independently-isolated phages expression of the cloned gene is reduced by loss of important regulatory sequences. One possible explanation is partial dominance of the mutant allele; e.g. the polypeptide product of the mutant gene competes with the wild-type gene product expressed by the phage. None of the three phages transduced the spoVJ mutation or a mutation in the nearby gerE gene.

spoVJ. Phages $\phi 105 \mathrm{~J} 81$ and $\phi 105 \mathrm{~J} 82$, which complemented mutation spoVJ517, did not transduce mutations in the spoVH or gerE loci. We can conclude, therefore, that the spoVH and spoVJ loci are indeed distinct.

Preliminary characterization of these new clones has therefore enabled us to clarify the genetic organization of several spo loci. Further physical and genetic characterization should enable us to understand the general features of sporulation operon organization. Although some of the new phages do not contain intact operons they nevertheless provide us with DNA probes that could be used to clone adjacent regions of the chromosome.

Several of the cloned loci, spoIIIA, spoIIIE, spoIIIF, spoIVF, spoVB, spoVH and spoVJ, have not apparently been isolated previously. Characterization of their regulation by applying methods such as gene fusions (Errington, 1986) or mRNA hybridization (Savva \& Mandelstam, 1986) should further our understanding of the patterns of regulation of sporulation genes. We have applied the former kind of analysis to four spo operons recently (Errington \& Mandelstam, $1986 a, b$; Clarke et al., 1986; Turner et al., 1986). However, one of the practical problems with these experiments has been in maintaining and repeatedly handling 40 or so different strains of B. subtilis containing mutations representative of each of the known spo loci. The transducing phages described here provide a rapid means of verifying the identity of spo mutations, which can now be applied to more than half of the strain collection.

In conclusion, transfection of protoplasts with vectors such as $\phi 105 \mathrm{~J} 27$ provides a versatile and effective system for cloning in $B$. subtilis. It seems likely that a range of applications for this system may be developed in the future.

We thank Ms Gillian Roberts for technical assistance, and Simon Cutting for isolating three of the new phages. We are grateful to Professor J. Mandelstam for invaluable advice and encouragement. The work was supported in part by the Science and Engineering Research Council. J.E. is the recipient of a Royal Society 1983 Research Fellowship.

\section{REFERENCES}

Chang, S. \& Cohen, S. N. (1979). High frequency transformation of Bacillus subtilis protoplasts by plasmid DNA. Molecular and General Genetics 168, 111-115.

Clarke, S., Lopez-Diaz, I. \& Mandelstam, J. (1986). Use of lac $Z$ gene fusions to determine the dependence pattern of the sporulation gene spoIID in spo mutants of Bacillus subtilis. Journal of General Microbiology 132, 2987-2994.

Coote, J. G. (1972a). Sporulation in Bacillus subtilis. Characterization of oligosporogenous mutants and comparison of their phenotypes with those of asporogenous mutants. Journal of General Microbiology 71, 1-15. 
CoOTE, J. G. (1972b). Sporulation in Bacillus subtilis. Genetic analysis of oligosporogenous mutants. Journal of General Microbiology 71, 17-27.

Cutting, S. M. \& Mandelstam, J. (1986). The nucleotide sequence and the transcription during sporulation of the gerE gene of Bacillus subtilis. Journal of General Microbiology 132, 3013-3024.

Dancer, B. N. \& Mandelstam, J. (1981). Complementation of sporulation mutations in fused protoplasts of Bacillus subtilis. Journal of General Microbiology 123, 17-26.

ERRINGTON, J. (1984). Efficient Bacillus subtilis cloning system using bacteriophage vector $\phi 105 \mathrm{~J} 9$. Journal of General Microbiology 130, 2615-2628.

ERrington, J. (1986). A general method for fusion of the Escherichia coli lac $Z$ gene to chromosomal genes in Bacillus subtilis. Journal of General Microbiology 132, 2953-2966.

ERRINGTON, J. \& MANDELSTAM, J. (1984). Genetic and phenotypic characterization of a cluster of mutations in the spoVA locus of Bacillus subtilis. Journal of General Microbiology 130, 2115-2121.

ErRington, J. \& MANDElstam, J. (1986a). Use of a lac $Z$ gene fusion to determine the dependence pattern of sporulation operon spoIIA in spo mutants of Bacillus subtilis. Journal of General Microbiology 132, 2967-2976.

Errington, J. \& Mandelstam, J. (1986 b). Use of a lac $Z$ gene fusion to determine the dependence pattern and the spore compartment expression of sporulation operon spoVA in spo mutants of Bacillus subtilis. Journal of General Microbiology 132, $2977-$ 2985.

Ferrari, F. A., Trach, K. \& Hoch, J. A. (1985a). Sequence analysis of the $\operatorname{spoOB}$ locus reveals a polycistronic transcription unit. Journal of Bacteriology 161, 556-562.

Ferrari, F. A., Trach, K., LeCoq, D., Spence, J., Ferrari, E. \& Hoch, J. A. (1985b). Characterization of the $\operatorname{spo} 0 A$ locus and its deduced product. Proceedings of the National Academy of Sciences of the United States of America 82, 2647-2651.

ForT, P. \& ERRINGTON, J. (1985). Nucleotide sequence and complementation analysis of a polycistronic sporulation operon, spoVA, in Bacillus subtilis. Journal of General Microbiology 131, 1091-1105.

ForT, P. \& PigGoT, P. J. (1984). Nucleotide sequence of sporulation locus spoIlA in Bacillus subtilis. Journal of General Microbiology 130, 2147-2153.

Fujita, M. \& Kobayashi, Y. (1985). Cloning of sporulation gene spoIVC in Bacillus subtilis. Molecular and General Genetics 199, 471-475.

HILL, S. H. (1983). spoVH and spoVJ-new sporulation loci in Bacillus subtilis 168. Journal of General Microbiology 129, 293-302.

Hoch, J. A. (1971). Selection of cells transformed to prototrophy for sporulation markers. Journal of Bacteriology 105, 1200-1201.

Hoch, J. A. \& Mathews, J. L. (1973). Chromosomal location of pleiotropic negative sporulation mutations in Bacillus subtilis. Genetics 73, 215-228.

Hranueli, D., Piggot, P. J. \& Mandelstam, J. (1974). Statistical estimate of the total number of operons specific for Bacillus subtilis sporulation. Journal of Bacteriology 119, 684-690.

Ionesco, H., Michel, J., Cami, B. \& Schaeffer, P.
(1970). Genetics of sporulation in Bacillus subtilis Marburg. Journal of Applied Bacteriology 33, 13-24.

Jenkinson, H. F. \& Mandelstam, J. (1983). Cloning of the Bacillus subtilis lys and spoIIIB genes in phage $\phi 105$. Journal of General Microbiology 129, 22292240 .

Jones, D. \& Errington, J. (1987). Construction of improved bacteriophage $\phi 105$ vectors for cloning by transfection in Bacillus subtilis. Journal of General Microbiology 133, 483-492.

Kobayashi, Y. \& Anaguchi, H. (1985). Cloning, amplification, and characterization of sporulation genes, especially spoIIG, of Bacillus subtilis. In Molecular Biology of Microbial Differentiation, pp. 85-94. Edited by J. A. Hoch \& P. Setlow. Washington, DC: American Society for Microbiology.

LAMONT, I. L. (1983). A detailed genetic analysis of closely-linked sporulation mutations in Bacillus subtilis. DPhil thesis, University of Oxford.

LAMONT, I. L. \& MANDELSTAM, J. (1984). Identification of a new sporulation locus, spoIIIF, in Bacillus subtilis. Journal of General Microbiology 130, 12531261.

Levi-Meyrueis, C., Fodor, K. \& Schaeffer, P. (1980). Polyethyleneglycol-induced transformation of Bacillus subtilis protoplasts by bacterial chromosomal DNA. Molecular and General Genetics 179, 589594.

Lopez-Diaz, I., Clarke, S. \& Mandelstam, J. (1986). spoIID operon of Bacillus subtilis: cloning and sequencing. Journal of General Microbiology 132, 341-354.

MoIR, A. (1981). Germination properties of a spore coat-defective mutant of Bacillus subtilis. Journal of Bacteriology 146, 1106-1116.

Piggot, P. J. (1973). Mapping of asporogenous mutations of Bacillus subtilis: a minimum estimate of the number of sporulation operons. Journal of Bacteriology 114, 1241-1253.

Piggot, P. J. \& CoOte, J. G. (1976). Genetic aspects of bacterial endospore formation. Bacteriological Reviews 40, 908-962.

Piggot, P. J. \& Hoch, J. A. (1985a). Revised genetic linkage map of Bacillus subtilis. Microbiological Reviews 49, 158-179.

Piggot, P. J. \& Hoch, J. A. (1985b). Genes controlling development in Bacillus subtilis. In Molecular Biology of Microbial Differentiation, pp. 1-7. Edited by J. A. Hoch \& P. Setlow. Washington, DC: American Society for Microbiology.

Piggot, P. J., Chak, K.-F. \& Bugaichuk, U. D. (1986). Isolation and characterization of a clone of the spoVE locus of Bacillus subtilis. Journal of General Microbiology 132, 1875-1881.

RAMAKRISHNA, N., DUBNAU, E. \& SMITH, I. (1984). The complete DNA sequence and regulatory regions of the Bacillus licheniformis spoOH gene. Nucleic Acids Research 12, 1779-1790.

Savva, D. \& Mandelstam, J. (1986). Synthesis of spoIIA and spoVA mRNA in Bacillus subtilis. Journal of General Microbiology 132, 3005-3011.

SCHAEFFER, P., IONESCO, H., RYTER, A. \& BALASSA, G. (1965). La sporulation de Bacillus subtilis: étude génétique et physiologique. Colloques internationaux du Centre national de la recherche scientifique Marseille 124, 553-563. 
Sterlini, J. M. \& Mandelstam, J. (1969). Commitment to sporulation in Bacillus subtilis and its relationship to the development of actinomycin resistance. Biochemical Journal 113, 29-37.

Stragier, P., Bouvier, J., Bonamy, C. \& SzulmajSTER, J. (1984). A developmental gene product of Bacillus subtilis homologous to the sigma factor of Escherichia coli. Nature, London 312, 376-378.

Trach, K. A., Chapman, J. W., Piggot, P. J. \& Hoch, J. A. (1985). Deduced product of the stage 0 sporulation gene spoOF shares homology with the Spo0A, OmpR, and SfrA proteins. Proceedings of the National Academy of Sciences of the United States of America 82, 7260-7264.

Turner, S. M., Errington, J. \& Mandelstam, J. (1986). Use of a lacZ gene fusion to determine the dependence pattern of sporulation gene spoIIIC in spo mutants of Bacillus subtilis: a branched pathway of expression of sporulation operons. Journal of General Microbiology 132, 2995-3003.

WaItes, W. M., KaY, D., DAWES, I. W., WoOD, D. A., Warren, S. C. \& MandelstaM, J. (1970). Sporulation in Bacillus subtilis. Correlation of biochemical events with morphological changes in asporogenous mutants. Biochemical Journal 118, 667-676.

Weir, J., Dubnau, E., Ramakrishna, N. \& Smith, I. (1984). Bacillus subtilis spoOH gene. Journal of Bacteriology 157, 405-412.

YouNG, M. (1975). Genetic mapping of sporulation operons in Bacillus subtilis using a thermosensitive sporulation mutant. Journal of Bacteriology 122 , 1109-1116. 